\title{
Penerapan Model Pembelajaran Terpadu untuk Mengukur Hasil Belajar Siswa SMP Negeri 3 Palu
}

\author{
Muhammad Zulkifli, Syamsu dan Sahrul Saehana \\ oel 281@yahoo.com \\ Program Studi Pendidikan Fisika FKIP Universitas Tadulako \\ Jl. Soekarno Hatta Km. 9 Kampus Bumi Tadulako Tondo Palu - Sulawesi Tengah
}

\begin{abstract}
ABSTRAK - Penelitian ini bertujuan untuk mengetahui ada tidaknya perbedaan hasil belajar IPA dengan menggunakan model pembelajaran terpadu tipe integrated dan model pembelajaran terpadu tipe connected pada siswa kelas VIII SMP Negeri 3 Palu. Jenis penelitian yang digunakan adalah eksperimen kuasi dengan desain "Non ekivalen pretest-posttest design". Sampel dipilih dengan menggunakan teknik purposive sampling dan menghasilkan kelas VIII F sebagai kelas eksperimen ke-1 dan kelas VIII G sebagai kelas eksperimen ke-2. Instrumen yang digunakan berupa tes hasil belajar dalam bentuk pilihan ganda. Berdasarkan hasil pengolahan data, diperoleh rerata skor pretest hasil belajar siswa kelas eksperimen ke-1 adalah 5,80 dengan standar deviasi 2,30, untuk rerata skor posttest adalah 14,97 dengan standar deviasi 2,06. Untuk kelas eksperimen ke2 diperoleh rerata skor pretest 6,23 dengan standar deviasi 2,06, sedangkan untuk rerata skor posttest adalah 13,17 dengan standar deviasi 2,65. Analisis data tes dilakukan dengan teknik statistik uji-t dua pihak untuk menguji perbedaan rerata skor hasil belajar siswa dengan taraf signifikan $a=0,05$. Diperoleh nilai hasil $t_{\text {hitung }}=$ 2,75 dan $t_{\text {tabel }}=2,00$. Ini berarti bahwa nilai $t_{\text {hitung }}$ berada diluar daerah penerimaan $H_{0}$. Sehingga dapat disimpulkan bahwa, ada perbedaan model pembelajaran terpadu tipe Integrated dengan model pembelajaran terpadu tipe connected terhadap hasil belajar IPA pada siswa kelas VIII SMP Negeri 3 Palu.
\end{abstract}

Kata Kunci : Tipe Integrated dan Tipe Connected, Hasil Belajar

\section{PENDAHULUAN}

Pembelajaran terpadu merupakan suatu pendekatan dalam pembelajaran yang dirancang dengan mengaitkan beberapa aspek baik dalam intra mata pelajaran maupun antar mata pelajaran. Dengan adanya pemaduan itu, siswa akan memperoleh pengetahuan dan ketrampilan secara utuh sehingga pembelajaran menjadi bermakna bagi siswa. Pembelajaran terpadu sangat memperhatikan kebutuhan siswa sesuai dengan perkembangannya yang holistik dengan melibatkan secara aktif dalam proses pembelajaran baik fisik maupun emosionalnya. Model pembelajaran terpadu sangat penting untuk kurikulum 2013 dikerenakan model pembelajaran ini memadukan keterkaitan antara konsep pada bidang studi satu dengan bidang studi lain pada mata pelajaran IPA.

Melalui penerapan model pembelajaran terpadu, diharapkan siswa dapat membangun pengetahuan melalui cara kerja ilmiah, bekerja sama dalam kelompok, belajar berinteraksi dan berkomunikasi,serta bersikap ilmiah. Pembelajaran terpadu merupakan paket pembelajaran yang menghubungkan konsep dari berbagai disiplin ilmu. Hal ini sesuai dengan prinsip pembelajaran bermakna, yaitu berkaitan dengan pengalaman hidupnya sehingga diharapkan dengan keterpaduan siswa dapat memandang suatu objek yang ada dilingkuanganya secara utuh.

Pendekatan pembelajaran terpadu merupakan suatu strategi yang memberikan kesempatan kepada siswa untuk mengembangkan potensinya secara seimbang, optimal, dan terpadu pula. Melalui proses pembelajaran terpadu siswa dilatih untuk bekerja sama, berekreasi, dan berkolaborasi dengan siswa lainnya atau pun guru, dalam mengembangkan ilmu maupun memecahkan masalah-masalah yang dihadapi ${ }^{[1]}$.

Ditinjau dari cara memadukan konsep, keterampilan, topik, dan unit tematisnya, terdapat 10 macam tipe model pembelajaran terpadu $^{[2]}$. Dari 10 model pembelajaran terpadu dipilih 2 untuk dibandingkan hasil belajarnya yaitu model tipe integrated dan model tipe connected, pemilihan dua tipe ini didasarkan pada pendekatan antar bidang studi dan hubungan dalam bidang studi itu sendiri. Materi IPA di SMP pada kurikulum 2013 memerlukan keterpaduan dan hubungan materi antara fisika dan biologi. Faktanya yang terjadi Materi IPA masih saja diajarkan secara terpisah, sehingga siswa menganggap materi dan konsep antara fisika dan biologi tidak ada hubunganya atau tidak berkaitan. 
Memilih model tipe integrated dan tipe connected karena kedua model ini masingmasing memiliki kelebihan. Kelebihan model pembelajaran terpadu tipe integrated diantara lain yaitu dimungkinkannya pemahaman antar bidang studi, memotivasi siswa dalam belajar dan, guru tidak perlu mengulangi kembali materi yang tumpang tindih, sehingga tercapailah efesiensi dan efektifitas pembelajaran. Sedangkan untuk tipe connected memiliki kelebihan sebagai berikut: dampak positif dari mengkaitkan ide-ide, siswa dapat mempunyai gambaran yang luas, siswa mengembangkan konsep-konsep kunci secara terus menerus sehingga terjadilah internalisasi, siswa dapat mengkaji, mengkonseptualisasi, memperbaiki, serta mengasimilasi ide-ide secara terus menerus sehingga memudahkan terjadinya proses transfer ide-ide dalam memecakan masalah ${ }^{[2]}$.

Pembelajaran terpadu tipe integrated (keterpaduan) adalah tipe pembelajaran terpadu yang menggunakan pendekatan antarbidang studi, menggabungkan bidang studi dengan cara menetapkan prioritas kurikuler dan menemukan keterampilan, konsep dan sikap yang saling tumpang tindih dalam beberapa bidang studi. Pada tipe ini tema yang berkaitan dan saling tumpang tindih merupakan hal terakhir yang ingin dicari dan dipilih oleh guru dalam tahap perencanaan program. Pembelajaran terpadu model connected (keterhubungan) menekankan pada perlu adanya integrasi inter bidang studi itu sendiri. Selain itu, model terhubung juga secara nyata menghubungkan satu konsep dengan konsep lain, satu topik dengan topik lain, satu keterampilan dengan keterampilan lain, tugas yang dilakukan dalam satu hari dengan tugas yang dilakukan pada hari berikutnya, serta ideide yang dipelajari pada satu semester dengan semester berikutnya ${ }^{[2]}$.

Berdasarkan uraian diatas penulis meneliti tentang perbedaan hasil belajar IPA antara model pembelajaran terpadu tipe integrated dan connected, dengan melalui tipe integrated dan tipe connected diharapkan siswa tidak hanya mampu mengingat fakta, hukum sains dan rumus-rumus yang ada. Tetapi lebih luas siswa dapat mengembangkan keterampilan berfikir dalam memahami konsep satu dan konsep yang lain pada mata pelajaran IPA, sehingga memudahkan mereka dalam memecakan permasalahan-permasalahan yang mereka hadapi dalam kehidupan nyata..

\section{METODE PENELITIAN}

Penelitian yang dilakukan adalah menggunakan metode kuasi dengan desain penelitian berupa "The equivalen pretestposttest design" atau rancangan pratespascates yang ekuivalen, yaitu memilih kelaskelas yang diperkirakan sama kondisinya. Artinya tingkat kecerdasannya hampir sama, sehingga kelas yang satu dijadikan sebagai kelas eksperimen pertama dan kelas yang satunya lagi dijadikan sebagai kelas eksperimen kedua. Jenis desain penelitian ini dapat dilihat pada Tabel $1^{[3]}$.

Tabel 1

Desain Penelitian : The equivalen pretest-posttest design

\begin{tabular}{lccc}
\hline Group & $\begin{array}{l}\text { Tes } \\
\text { Awal }\end{array}$ & Perlakuan & $\begin{array}{l}\text { Tes } \\
\text { Akhir }\end{array}$ \\
\hline $\begin{array}{l}\text { Kelas } \\
\text { Eksperimen ke-1 }\end{array}$ & $\mathrm{O}_{1}$ & $\mathrm{X}_{1}$ & $\mathrm{O}_{2}$ \\
$\begin{array}{l}\text { Kelas } \\
\text { Eksperimen Ke-2 }\end{array}$ & $\mathrm{O}_{1}$ & $\mathrm{X}_{2}$ & $\mathrm{O}_{2}$ \\
\hline
\end{tabular}

Keterangan :

$\mathrm{X}_{1}$ : Kelompok dengan Tipe Integrated

$\mathrm{X}_{2}$ : Kelompok dengan Tipe Connected

$\mathrm{O}_{1}$ : Tes awal (pretest)

$\mathrm{O}_{2}$ : Tes akhir (posttest)

Populasi dari penelitian ini adalah seluruh siswa kelas VIII di SMP Negeri 3 Palu tahun ajaran 2015-2016. Pengambilan sampel dilakukan dengan menggunakan teknik penentuan sampel dengan pertimbangan tertentu (Purposive Sampling) ${ }^{[4]}$ yaitu dengan pertimbangan kemampuan siswa dengan cara mengetahui keadaan sebelumnya terhadap nilai hasil belajar siswa yang dimiliki guru sebagai bahan pertimbangan penentuan sampel yaitu memilih kelas yang hasil ujian rata - ratanya hampir sama yang dilakukan oleh guru mata pelajaran dan peneliti.

\section{HASIL DAN PEMBAHASAN}

Hasil dari pemberian tes yang mengacu pada soal hasil belajar IPA yang diberikan pada kelas eksperimen 1 dan kelas eksprimen 2 disajikan pada Tabel 2 .

Tabel 2 Deskripsi skor tes hasil belajar IPA untuk kelas eksperimen 1 dan kelas eksprimen 2

\begin{tabular}{ccccc}
\multirow{2}{*}{ Uraian } & \multicolumn{2}{c}{ Pretest } & \multicolumn{2}{c}{ Posttest } \\
\cline { 2 - 5 } & $\begin{array}{c}\text { Eksperi } \\
\text { men 1 }\end{array}$ & $\begin{array}{c}\text { Ekspri } \\
\text { men 2 }\end{array}$ & $\begin{array}{c}\text { Eksperi } \\
\text { men 1 }\end{array}$ & $\begin{array}{c}\text { Eksperi } \\
\text { men 2 }\end{array}$ \\
\hline Sampel (n) & 30 & 30 & 30 & 30 \\
\hline
\end{tabular}




\begin{tabular}{ccccc}
\hline $\begin{array}{c}\text { Nilai } \\
\text { maksimum } \\
\text { Nilai } \\
\text { minimum }\end{array}$ & 11 & 11 & 19 & 18 \\
$\begin{array}{c}\text { Skor rata- } \\
\text { rata }\end{array}$ & 5,80 & 6,23 & 15 & 13,17 \\
$\begin{array}{c}\text { Standar } \\
\text { deviasi }\end{array}$ & 3.15 & 2,16 & 2,29 & 2,75 \\
\hline
\end{tabular}

Adapun persentase perolehan dari skor ratarata hasil belajar IPA pada siswa baik tes awalnya maupun tes akhirnya dapat dilihat pada Gambar 1 dan 2.

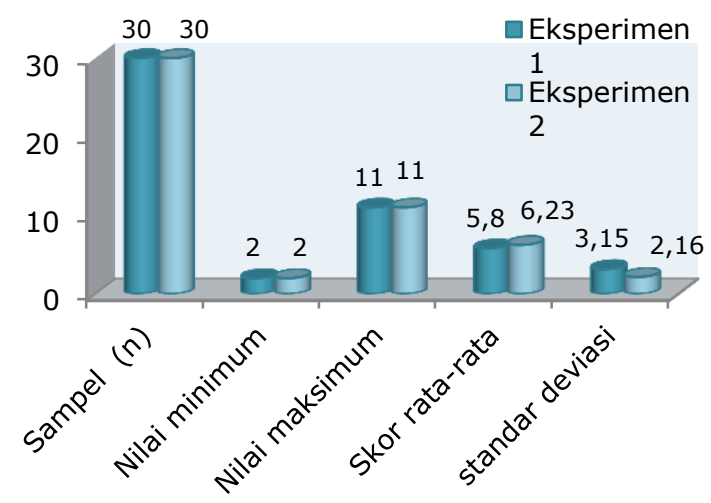

Gambar 1 : Sampel, Nilai Maksimum, Nilai Minimum, Skor rata-rata dan Standar Deviasi Tes Akhir (Pretest) Kelas Eksperimen 1 dan Kelas Eksperimen 2

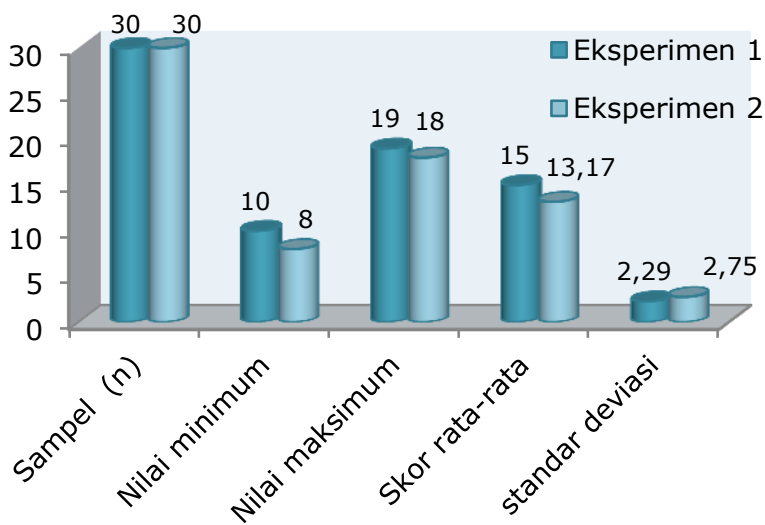

Gambar 2 : Sampel, Nilai Maksimum, Nilai Minimum, Skor rata-ratadan Standar Deviasi Tes Akhir (Posttest) Kelas Eksperimen 1 dan Kelas Eksperimen 2

Berdasarkan pada gambar 1 dapat dilihat tidak terdapat perbedaan dalam hasil belajar IPA pada kedua kelas tersebut sehingga kedua kelas bisa dikatakan memiliki pemahaman awal yang sama mengenai materi tersebut. Pada gambar 2 terdapat perbedaan hasil belajar IPA dari kedua kelas tersebut yaitu antara kelas eksperimen 1 dan kelas eksperimen 2.
Berdasarkan nilai rata-rata pretest kelas eksperimen 1 sebesar 5,80 dan kelas eksperimen 2 sebesar 6,23, dilakukan uji hipotesis (Uji-t) beda rata-rata (dua pihak) dan diketahui nilai $t_{\text {hitung }}=-0,72$. Selanjutnya untuk nilai $t_{\text {tabel }}$ dimana $t_{\text {tabel }}=t_{(1-1 / 2 a)}$ pada taraf nyata $a=0,05$ dan $\mathrm{dk}=\left(\mathrm{n}_{1}+\mathrm{n}_{2}-2\right)=$ $30+30-2=58$, diperoleh $t_{0,975(58)}=2,00$. Data tersebut disajikan pada tabel 3 berikut.

Tabel 3 : Uji beda rata-rata (dua pihak) Pretest Kelas Eksperimen 1 dan Kelas Eksperimen 2

\begin{tabular}{cccccc}
\hline No & Kelas & $\begin{array}{c}\text { Nilai rata- } \\
\text { rata } \bar{X}\end{array}$ & thitung $_{\text {habel }}$ & $\begin{array}{c}\text { keputus } \\
\text { an }\end{array}$ \\
\hline 1 & VIII F & 5,80 & $-0,72$ & 2,00 & $\begin{array}{c}\text { Ho } \\
\text { diterima }\end{array}$ \\
\hline
\end{tabular}

Berdasarkan data Tabel 3 dan kriteria pengujian dimana $\mathrm{H}_{0}$ diterima jika $-\mathrm{t}_{(1-1 / 2 \mathrm{a})}<\mathrm{t}<$ $\mathrm{t}_{(1-1 / 2 \mathrm{a})}$, diketahui $-2,02<-0,72<2,02$. Nilai $t_{\text {hitung }}$ berada pada daerah penerimaan $\mathrm{H}_{0}$. Dengan kata lain, bahwa tidak terdapat perbedaan hasil belajar IPA siswa antara kelas yang mendapatkan pembelajaran menggunakan model tipe Integrated dengan kelas yang mendapatkan pembelajaaran menggunakan model tipe connected. Tidak adanya perbedaan hasil pretest menunjukkan bahwa kedua kelas memiliki kemampuan awal yang sama, sehingga kedua kelas ini memenuh syarat untuk dijadikan sampel. Berdasarkan nilai ratarata posttest kelas eksperimen 1 sebesar 15,17 dan kelas eksperimen 2 sebesar 13,17, dilakukan uji hipotesis (Uji-t) dan diketahui nilai $t_{\text {hitung }}=2,75$. Selanjutnya untuk nilai $t_{\text {tabel }}$ dimana $t_{\text {tabel }}=t_{(1-1 / 2 a)}$ pada taraf nyata $a=$ 0,05 dan $\mathrm{dk}=\left(\mathrm{n}_{1}+\mathrm{n}_{2}-2\right)=30+30-2=58$, diperoleh $t_{0,975(58)}=2,00$. Data tersebut disajikan pada Tabel 4 berikut.

Tabel 4 : Uji Hipotesis (dua pihak) Posttest Kelas Eksperimen 1 dan Kelas Eksperimen 2

\begin{tabular}{cccccc}
\hline No & Kelas & $\begin{array}{c}\text { Nilai rata- } \\
\text { rata } \bar{X}\end{array}$ & $\mathbf{t}_{\text {hitung }}$ & $\mathbf{t}_{\text {tabel }}$ & $\begin{array}{c}\text { keputus } \\
\text { an }\end{array}$ \\
\hline 1 & VIII F & 14,97 & 2,75 & 2,00 & $\begin{array}{c}\text { Ho } \\
\text { ditolak }\end{array}$ \\
\hline
\end{tabular}

Berdasarkan data Tabel 4 diketahui $t_{\text {hitung }} \geq t_{\text {tabel }}$ atau $2,75 \geq 2,00$. Hal ini berarti,nilai thitung berada di luar daerah penerimaan $\mathrm{H}_{0}$. Dengan demikian $\mathrm{H}_{0}$ ditolak dan $\mathrm{H}_{1}$ diterima, dan dapat disimpulkan bahwa terdapat perbedaan ratarata hasil belajar IPA antara kelompok siswa yang mengikuti model pembelajaran terpadu tipe integtated dengan model pembelajaran terpadu tipe connected. Dengan kata lain, nilai 
hasi belajar kelas eksperimen 1 lebih tinggi dibanding dengan kelas eksperimen 2 .

Penelitian dilakukan dengan cara memberikan dua perlakuan yang berbeda yaitu pembelajaran tipe integrated di kelas eksperimen ke-1 dan pembelajaran tipe connected pada kelas eksperimen ke-2. Berdasarkan hasil pengolahan data yang dilakukan, dilihat bahwa kemampuan awal siswa masih rendah dan sama kedua kelas kemampuannya. Hal ini dapat diketahui dari pemberian tes awal (pretest) pada kelas VIII $\mathrm{F}$ dengan skor rata-rata sebesar 5,8 sedangkan skor rata-rata pada kelas VIII G sebesar 6,23. Dari pretest tersebut dapat dilihat bahwa kemampuan siswa pada kelas eksperimen ke-1 dan kelas eksperimen ke-2 sama. Untuk pemberian tes akhir (posttest) pencapaian skor rata-rata pada kelas eksperimen ke-1 (VIII F) sebesar 14,97 sedangkan pada kelas eksperimen ke-2 (VIII G) sebesar 13,17. Dari hasil penelitian tersebut dapat diketahui bahwa skor rata-rata kelas eksperimen ke-1 lebih tinggi dari pada kelas eksperimen ke-2. Kemudian berdasarkan uji normalitas prestest ataupun posttest bahwa data yang diperoleh terdistribusi normal dan mempunyai varians yang homogen.

Berdasarkan hasil penelitian tersebut dapat diketahui bahwa dengan memberikan perlakuan yang berbeda pada kelas eksperimen ke-1 dan kelas eksperimen ke-2, akan memperoleh hasil belajar yang berbeda. Perbedaan hasil belajar tersebut dapat dilihat dari skor rata-rata tes akhir (posttest) pada kelas eksperimen ke-1 dan kelas eksperimen ke-2 yang menunjukkan adanya pengaruh model pembelajaran yang digunakan pada kedua kelas tersebut. Pengaruh hasil belajar yang lebih besar terjadi pada kelas eksperimen ke-1, karena pada siswa mendapatkan pengalaman belajar lebih luas dari segi materi yang menghubungkan IPA dengan bidang studi diluar kajian IPA, sehingga siswa terbantu untuk menciptakan kesempatan lebih luas untuk melihat dan membangun konsep-konsep yang berkaitan untuk mendapatkan pembelajaran lebih bermakna dan secara utuh.

Berdasarkan penelitian yang dilakukan diketahui bahwa kedua kelas tersebut memiliki kemampuan yang hampir sama. Hal ini dapat dilihat dari skor rata-rata yang telah diperoleh dari kedua kelas tersebut. Tetapi materi dan konsep yang diterima kedua kelas yang membedakan. Dimana pada kelas eksperimen ke-1 yang menggunakan model pembelajaran terpadu tipe integrated, siswa mendapatkan materi dan konsep lebih luas dengan cara menggabungkan bidang studi IPA dengan bidang studi matematika, dimana pada soalsoal IPA fisika identik dengan bentuk soal cerita. Pada mata pelajaran matematika terdapat juga materi menyeleseaikan soal-soal cerita yang merupakan penerapan sistem persamaan linear dua variabel dimulai dengan menerjemakan soal tersebut ke dalam model matematika dalam bentuk persamaan, dengan menggabungkan kedua konsep tersebut dapat mempermudah siswa dalam menyelesaikan soal-soal berbetuk soal cerita. Pada kelas eksperimen ke-2 yang menggunakan model pembelajaran terpadu tipe connected, siswa mendapatkan materi dan konsep dengan cara menghubungkan satu konsep dengan konsep yang lainnya, satu topik dengan topik lainnya pada bidang studi itu sendiri. Dimana pada mata pelajaran IPA diperlukan hubungan antara konsep fisika dengan konsep biologi yang saling berkaitan dan tumpang tindih. Hal inilah yang mengakibatkan perbedaan hasil belajar yang diperoleh kedua kelas tersebut.

Penggunaan model pembelajaran terpadu tipe integrated pada kelas eksperimen ke-1 lebih baik dalam hasil belajar IPA daripada kelas eksperimen ke-2 yang menggunakan model pembelajaran terpadu tipe connected. Hal ini dapat diperoleh dari skor pretest maupun skor posttest. Perbedaan tersebut dipengaruhi oleh perlakuan yang diberikan pada kelas eksperimen ke-1 dan kelas eksperimen ke-2 berbeda.

Berdasarkan hasil penelitian yang telah dilakukan bahwa model pembelajaran terpadu tipe integrated dan tipe connected terdapat perbedaan hasil belajar siswa. Hal ini sesuai dengan ungkapan Yunitha (2013), bahwa perbedaan yang signifikan hasil belajar IPA antara siswa yang dibelajarkan menggunakan model pembelajaran terpadu tipe connected dengan pembelajaran konvensional. Berdasarkan pernyataan tersebut menunjukkan bahwa pembelajaran tipe connected lebih baik dalam pembelajaran IPA dibandingkan pembelajaran konvesional ${ }^{[5]}$. Di sisi lain berdasarkan penelitian Tayyib (2013), mengungkapkan bahwa model integrated dan model connected sama-sama dapat meningkatan motivasi belajar IPA peserta $\operatorname{didik}^{[6]}$.

Dari hasil temuan tersebut dapat dilihat kedua model tersebut sama-sama dapat meningkatkan hasil belajar siswa, tetapi yang 
menjadi perbedaan antara kelas eksperimen ke-1 yang menggunakan model pembelajaran terpadu tipe integrated yang menggabungkan bidang studi yang satu dengan bidang studi yang lain, sedangkan kelas eksperiemen ke-2 yang menggunakan model pembelajaran terpadu tipe connected menghubungkan konsep-konsep dan topik pada bidang studi itu sendiri. Perbedaan tersebut menunjukkan adanya pengaruh model pembelajaran yang digunakan pada kelas eksperimen ke-1 dan kelas eksperimen ke-2.

\section{KESIMPULAN DAN SARAN}

Berdasarkan penelitian dan analisis data dapat disimpulkan bahwa ada perbedaan hasil belajar IPA dengan menggunakan model pembelajaran terpadu tipe integrated dan model pembelajaran terpadu tipe connected pada siswa kelas VIII SMP Negeri 3 Palu. Hal ini dapat dilihat dari rerata skor pretest kelas eksperimen ke-1 adalah 5,80 dan rerata skor posttest 14,97, untuk kelas eksperimen ke-2 diperoleh rerata skor pretest 6,23 dan untuk rerata skor posttest adalah 13,17. Berdasarkan analisis data tes dilakukan dengan teknik statistik uji-t dua pihak untuk menguji perbedaan rerata skor hasil belajar siswa dengan taraf signifikan $a=0,05$. Diperoleh nilai hasil thitung $=2,75$ dan ttabel $=2,00$. Adanya perbedaan tersebut dipengaruhi oleh perbedaan dalam pemberian materi yang diberikan dalam pembelajaran pada kedua kelas yaitu dengan cara menghubungkan materi, konsep pada intra mata pelajaran IPA dan menggabungkan materi antara mata pelajaran IPA dan Matematika.

Berdasarkan hasil penelitian dan analisis data pada penelitian mengenai model pembelajaran terpadu tipe integrated dan model pembelajaran terpadu tipe connected, maka peneliti menyarankan :

1. Model pembelajaran IPA terpadu dengan menggunakan model tipe integrated dan tipe connected dapat dijadikan alternatif model pembelajaran untuk meningkatkan pemahaman konsep dan motivasi siswa.

2. Dalam menggunakan model pembelajaran terpadu tipe integrated dan tipe connected guru harus mengetahui langkah-langkah pembelajaran yang akan digunakan agar jelas dan terarah dengan benar, kerena pada prinsipnya guru hanya sebagai fasilitator dan motivator.
3. Materi dan konsep yang akan dipadukan guru harus sangat menguasahi materi dan konsep yang telah dipadukan.

\section{DAFTAR PUSTAKA}

[1] Trianto. 2010. Model Pembelajaran Terpadu. Jakarta. PT Bumi Aksana

[2] Fogarty. 1991. Ten Ways to Integrate Curriculum. In Robin Fogarty (Ed), (1993), Integrating the Curricula, p.102. Hawker Brownlow Education:Australia).

[3] Sudjana. (2005). Metode Statistika. Bandung: CV. Tarsito.

[4] Sugiyono. (2009). Metode Penelitian Kuantitatif Kualitatif dan $R \& D$. Bandung: Alfabeta.

[5]Yunitha S, dkk. 2013. Pengaruh Model Pembelajaran Terpadu Tipe Connected Terhadap Hasil Belajar IPA Siswa Kelas VII SMP. (Jurnal Pillar Of Physics Education, Volume 1 No. 1, Febuari 2013, ISSN : 9721 1821).

[6]Tayyib F. 2013. Perbedaan Model Pembelajaran IPA Terpadu Tipe Integrated dengan Tipe Connected Terhadap Peningkatan Motivasi Belajar Peserta Didik SMP Negeri 2 Ngrampal. Yogyakarta. Digital Library : Skripsi Tidak Terpublikasikan 